\title{
Species Distribution Modeling And Assessment of Environmental Drivers Responsible To Distribution And Preferred Niche of Critically Endangered Endemic Ornamental Freshwater Fish Species of The Genus Sahyadria
}

Ajey Kumar Pathak ( $\square$ pathakajey@gmail.com )

National Bureau of Fish Genetic Resources

Pushpendra Verma

National Bureau of Fish Genetic Resources

Rajesh Dayal

National Bureau of Fish Genetic Resources

Uttam Kumar Sarkar

CIFRI: Central Inland Fisheries Research Institute

\section{Research Article}

Keywords: MaxEnt, Sahyadria, Spatial distribution modeling, Occurrence, Western Ghats, Endangered freshwater fish

Posted Date: June 11th, 2021

DOl: https://doi.org/10.21203/rs.3.rs-538109/v1

License: (c) (i) This work is licensed under a Creative Commons Attribution 4.0 International License. Read Full License 


\section{Abstract}

India has different bio-climatic zones that support diverse aquatic habitats rich in biodiversity. For effective conservation of endangered species in its habitat, it is essential to know the distribution of the fish species in the environmental range and for this species distribution models are the efficient and innovative tools. The present study used MaxEnt model to develop the probability distribution model highlighting the distribution of the fish species by analyzing the known occurrence records of Denison barb under genus Sahyadria (Sahyadria denisonii Day 1865 and Sahyadria chalakkudiensis (Menon, Rema Devi \& Thobias 1999)) in relation to environmental variables typically incorporating seasonal and temporal variability. AUC of the models for Sahyadria species depicted good fitness. Both the species were found sensitive to 'Solar radiation', 'Temperature seasonality' and 'Temperature annual range' and these variables were assessed as the significant predictors. The sensitivity of distribution of both species to these environmental variables was found correlated with their breading and spawning seasons. 'Precipitation' was determined as a significant climatic envelop influencing distribution of the species associated with the river flow. The models showed that distribution of $S$. denisonii in the higher precipitation areas compared to $S$. chalakkudiensi. The probability distribution model with respect to distribution of both the species indicates a lineage barrier at Palghat Gap supporting the studies of earlier workers. At the latitudinal scale, prediction of the suitable ecological habitat provides the detailed insight into the distribution of all the genetic lineages of the genus Sahyadria. Evidently, the findings of this study can assist in determining ecological niches for other threatened and endangered species of other areas and may aid in field surveys as well as developing conservation plans.

\section{Introduction}

The loss of biodiversity is a major vulnerability affecting the aquatic ecosystem in India due to anthropogenic and climatic changes (Dudgeon et al., 2006; Sarkar et al., 2020). The freshwater fish fauna of the Western Ghats in India is one of the richest and unique in the tropical world. This region lists 288 freshwater fishes, of which $118(41 \%)$ are endemic to the Western Ghats (Dahanukar et al.2004; Dayal et al. 2014). Amongst the listed endemic species, genus Sahyadria is represented by two species, Sahyadria denisonii (Day, 1865) and Sahyadria chalakkudiensis (Menon et al., 1999) and both species are commercially important ornamental freshwater species endemic to the Western Ghats. These two species look alike but, there are six evolutionary distinct lineages between these species (John et al., 2013b). The population of both the species of genus Sahyadria is declining because of exploitation for export (Raghavan et al., 2013), restricted range, and deterioration in its habitats (Ali et al., 2015; Raghavan et al., 2018). Now, both the species are listed under endangered category according to the IUCN Red List Criteria (Version 2020-21.) inviting focused research on the conservation biology and immediate attention for effective conservation and restoration plan. Both species are benthopelagic and herbivorous of which $S$. denisonii inhabits fast flowing hill streams and S. chalakkudiensis inhabits upper reaches of river with over growing plants (Raghvan et al., 2013). The general distribution of $S$. denisonii covers Mundakayam, 
Travancore hill ranges, Aralam Wildlife sanctuary and Kannur district of Kerala. S. challakudiensis is only distributed in the river Chalakudi, Kerala (Ponniah and Gopalakrishnan 2000).

The global anthropogenic climate change is known to impact inland aquatic ecosystems and life history events such as distribution, habitat utilization, breeding phenology, ultimately deteriorating the existing natural fish population (Sarkar et al., 2019). It has implications for both biodiversity conservation as well as fisheries exploitation. In order to develop proper conservation of the target species, spatial and temporal data on the species distribution and habitat are needed for assessing and predicting the status. Although limited research has been carried out at the global level and methods as well as models have been predicted for inland fish distribution at ecological /evolutionary perspectives but, in India focused research in this regard has not been addressed so far.

Prediction of the fish distribution and change in the land use pattern are essential for developing plans for conservation of biodiversity. The information on the geographic distribution of species has been documented using the predictive models, which is important for a variety of applications in the ecology and conservation (Graham et al., 2004). Species distribution models (SDMs) are the efficient tools to predict the geographic and environmental range of a species, typically incorporating seasonal and temporal variability both. SDMs estimate the relationship between the species records at sites and the environment and/or spatial characteristics of those sites (Franklin, 2010). SDMs are widely used for stream bioassessment, estimating changes in the habitat suitability and identifying conservation priorities. In the last two decades, many developments have been made in the field of SDM and multiple methods are available now (Austin, 2007; Elith et al., 2006), of which many have been used to predict the distribution of fishes by predicting the suitable habitat (Buisson et al., 2008; Mcnyset, 2005; Oakes et al.,2005). Moreover, a recent comprehensive comparison of presence-only modeling techniques (Elith et al., 2006) highlights that some new methods have better predictive accuracy than the established methods and among new methods Maximum Entropy Species Distribution Modeling (MaxEnt) (Elith et al., 2006; Phillips et al.,2004) is better to optimize predictive accuracy. A major distinction among these methods is the kind of species data it use and the accuracy, which is critical for guiding effective stream management decisions (Rose et al., 2016). Recent survey of literatures suggests that species distribution model could be better if more ecological theory is included by taking species - environment relationship in consideration (Austin, 2007; Guisan et al., 2013). Thus, modeling the distribution of a species largely depends on the data and the model parameters and the uncertainties derived from these. Therefore, it is essential to adopt the best practice in modeling the species distribution by identifying the data limitations and understanding the elements and methods involved in the SDM.

In a fish assemblage, species differ in life history strategies, habitat requirements, and sensitivities to the stressors (Maloney et al., 2006; Schleiger, 2000; Schlosser, 1982), thus generalized conservation plan will not always be suitable for the species of interest. In this case species distribution model for the species of interest will serve the conservation purpose better. The spatial and temporal distribution of species diversity is a major aspect in ecological studies, and its relevance is pertinent in the climate change scenario as well as habitat degradation/alteration and aquatic diversity loss (McGill et al 2015). In India, 
the conceptualization of methods and developing models to study inland fish biology, habitat and distribution has not been attempted except food web model ( Panikkar and Khan 2008, Khan et al 2015) and model based reproductive vulnerability assessment in changing environmental scenario(Sarkar et al $2019,2021)$. In view of the aforesaid facts, this study aims to develop model based fish distribution prediction of the two species having high conservation significance, Sahyadria denisonii and Sahyadria chalakkudiensis of Genus Sahyadria using MaxEnt model. The ultimate goal of the present study is to understand the spatial distribution pattern, ecological niche of each species and assess environmental factors affecting the distribution. Generating knowledge on the present state of distribution of the two endangered endemic species, their essential fish habitat and responsible environmental concerns will be an important step toward conserving these endangered species in its region.

\section{Materials And Methods 1. Data collection}

\section{1a. Species occurrence records}

The locality occurrence records of the species of genus Sahyadria with longitude and latitude for each occurrence sites were collected from publications of the natural history museums, published literature and reliable observational datasets (Table 1 and Table 2). We got few records where maps were available for a locality and for such records maps were georeferenced to assign the geographical coordinates for the locality. Thereafter, the complete dataset holding the occurrence records of the species of genus Sahyadria was screened for finding errors in georeferencing and taxonomic status. To avoid the sampling bias we applied spatial filtering and used only 1 sample from a locality in such a way that no two samples lay within $5 \mathrm{~km}$ radius (Kramer et al., 2013). Finally, the error free presence only dataset as the locality occurrence datasets of these two species was used in the study to develop the distribution model of the endemic and endangered species of the region (Hernandez et al., 2008). 
Table 1

Details on occurrence of Sahyadria denisoni reported from different river system by different authors used in modelling

\begin{tabular}{|c|c|c|}
\hline \multirow{2}{*}{$\begin{array}{l}\text { S. } \\
\text { No. }\end{array}$} & \multirow[t]{2}{*}{ River system (North to South) } & Sahyadria denisonii \\
\hline & & Occurrence data used in study \\
\hline 1 & Payaswini River System & John, 2009; John et al., 2013b; Radhakrishnan, 2006 \\
\hline 2 & Karyangod River System & John, 2009 \\
\hline 3 & Thejaswini River System & John et al., 2013b; Radhakrishnan, 2006 \\
\hline 4 & Bavali River System & John, 2009; John et al., 2013b; Radhakrishnan, 2006 \\
\hline 5 & Chaliyar River System & John, 2009; John et al., 2013b \\
\hline 6 & $\begin{array}{l}\text { Bharathappuzha River System / } \\
\text { PalGhat Gap biogeographic } \\
\text { barrier }\end{array}$ & Radhakrishnan, 2006 \\
\hline 7 & Chalakkudy River System & John, 2009; John et al., 2013b; Radhakrishnan, 2006 \\
\hline 8 & Periyar River System & $\begin{array}{l}\text { John, 2009; John et al., 2013b; Johnson and Arunachalam, } \\
2009 ; \text { Radhakrishnan and Kurup, 2006; Radhakrishnan, } \\
2006\end{array}$ \\
\hline 9 & Pampa River System & John et al., 2013b; Kurup and Radhakrishnan, 2006) \\
\hline 10 & Achenkoil River System & (Radhakrishnan, 2006) \\
\hline
\end{tabular}

Table2 Details on occurrence of Sahyadria chalakkudiensis reported from different river system by different authors used in modelling

\begin{tabular}{lll} 
S. No. & River system (North to South) & $\begin{array}{l}\text { Sahyadria chalakkudiensis } \\
\text { Occurrence data used in study }\end{array}$ \\
& & \\
\hline 1 & Chalakkudy River System & (John et al., 2013b; Menon et al., 1999) \\
\hline 2 & Periyar River System & (John et al. 2013) \\
\hline 3 & Pampa River System & (Arunachalam et al., 2013; John et al., 2013b) \\
4 & Achenkoil River System & (Baby et al., 2011) \\
\hline
\end{tabular}

\section{1b. Environmental dataset}


The environmental dataset holds the records comprising climate, hydrology and topography datasets. All these datasets were downloaded and used in the study to develop the probability spatial distribution models of the species of the genus Sahyadria. For climate, WorldClim Version 2.0 (Fick \& Hijmans, 2017) is a database of high spatial resolution global weather and climate data. This is a new release, which is a set of global climate layers (gridded climate data). This data can be used for mapping and spatial modeling. In this database, there are monthly climate data for minimum, mean, and maximum temperature, precipitation, solar radiation, wind speed, water vapor pressure, and total precipitation. Moreover, there are also 19 bioclimatic variables. Each climate data download is a 'zip' file containing 12 GeoTiff (.tif) files, one for each month of the year (January is 1; December is 12). The 19 bioclimate variables are the average for the years 1970-2000. Each download is a 'zip' file containing 19 GeoTiff (.tif) files, one for each month of the variables. In the present study, for environmental data all the 7 climate $(7 * 12$ month $=84)$ and 19 bioclimatic variables (Table 3$)$ with a spatial resolution of 30 seconds $\left(\sim 1 \mathrm{~km}^{2}\right)$ were used. For hydrology, Global Multi-Resolution Terrain Elevation data GMTED 2010 database, which is a replacement of GTOPO30 was used to derive data for entire India with a spatial resolution of $30 \mathrm{~m}$ on different hydrological and topographical variables. This new product suite provides global coverage of all land areas. In the present study, only the mean dataset available in GMTED for India was used for deriving the values of different hydrological parameters. The values of the hydrological parameters listed in Table 3 were derived by applying the $\mathrm{A}^{\top}$ Search Algorithm developed by Ehlschlaeger (1989) using GRASS GIS (Version 7.8.1) software. $A^{\top}$ Search Algorithm also known as least cost search is a method, which identifies drainage flow directly from the original elevation data. From the prepared dataset of the hydrological variables, the two topographical variables 'landscape slope' and 'aspect' were derived using the above mentioned GIS software. The basin and drainage maps were overlaid on the Google maps for identification of river reaches. The river reaches were isolated by digitizing and annotated too. 
Table 3

Climate, bioclimatic variables available in WorldClim Version 2.0 database, the hydrological variables derived from the mean dataset available in GMTED for India and the topographical variables used in the study

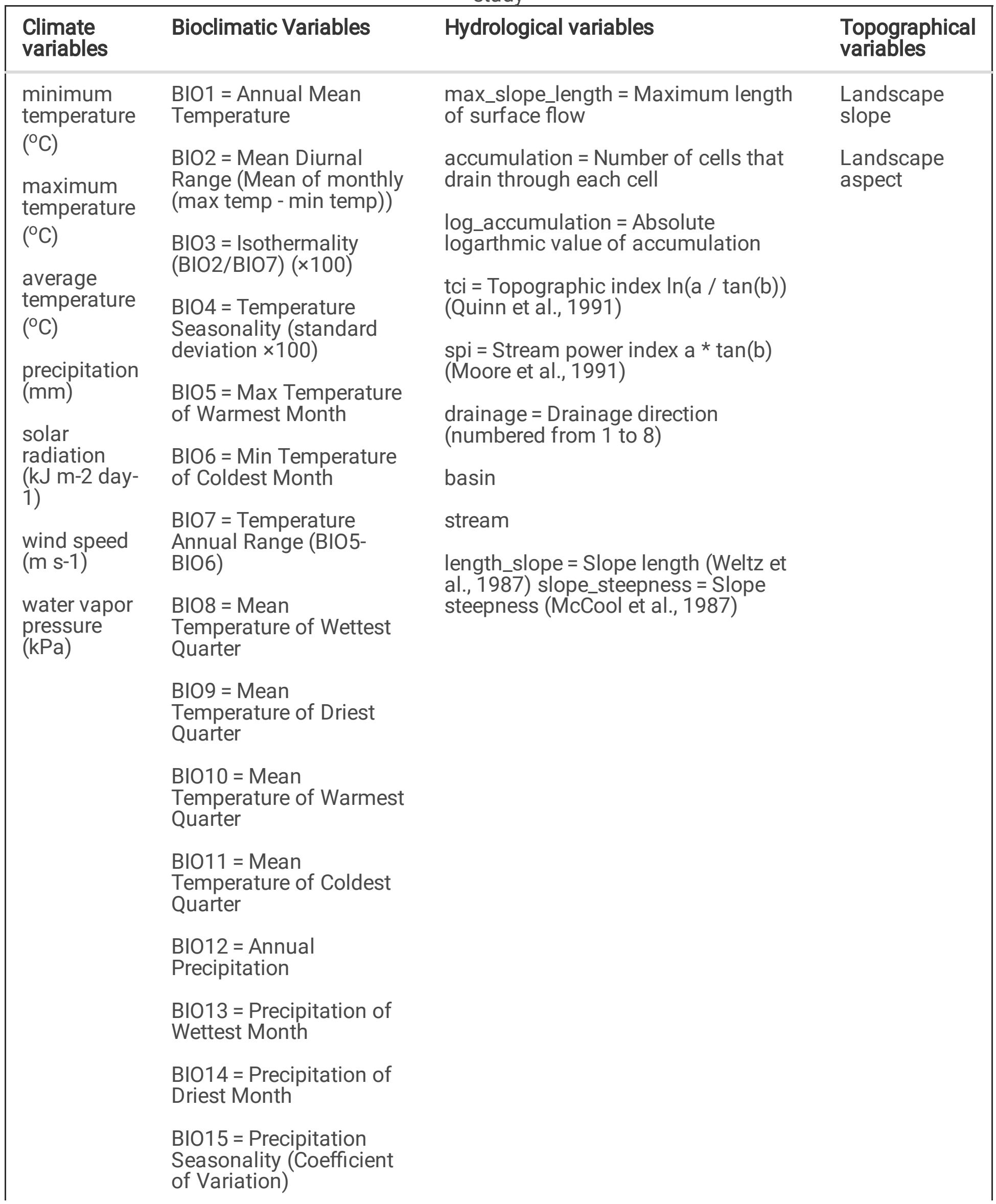




\begin{tabular}{|c|c|c|c|}
\hline \multirow[t]{5}{*}{$\begin{array}{l}\text { Climate } \\
\text { variables }\end{array}$} & Bioclimatic Variables & Hydrological variables & $\begin{array}{l}\text { Topographical } \\
\text { variables }\end{array}$ \\
\hline & $\begin{array}{l}\text { BIO16 = Precipitation of } \\
\text { Wettest Quarter }\end{array}$ & & \\
\hline & $\begin{array}{l}\text { BIO17 = Precipitation of } \\
\text { Driest Quarter }\end{array}$ & & \\
\hline & $\begin{array}{l}\text { BIO18 = Precipitation of } \\
\text { Warmest Quarter }\end{array}$ & & \\
\hline & $\begin{array}{l}\text { BIO19 = Precipitation of } \\
\text { Coldest Quarter }\end{array}$ & & \\
\hline
\end{tabular}

\section{Species distribution modeling}

Elevation in the two adjoining pixels can fluctuate significantly but not the climate therefore, resampling of the elevation data to the finer resolution can severely reduce the quality of hydrological data but resampling of the climatic data to the finer resolution cannot affect much hence, we resampled the climate data of 30 second using Lanczos interpolation (Lanczos, 1938) to transform the data to a finer grid of spatial resolution $30 \mathrm{~m}$ to match with the elevation data. All the GIS analysis was done using GRASS GIS (Version 7.8.1) software. A method called maximum entropy distribution or MaxEnt was used for modeling the species distribution because this model performs the best among many modeling methods (Elith et al., 2006) and its effectiveness over small sample size (Benito et al., 2009; Hernandez et al., 2006; Papeş \& Gaubert, 2007; Pearson, 2007; Wisz et al., 2008). MaxEnt is a maximum entropy based machine learning program that estimates the probability distribution from the species' occurrence data based on the environmental constraints (Phillips et al., 2004). It requires only species presence data and environmental variable (continuous or categorical) layers of the study area. The freely available MaxEnt software, version 3.1 was downloaded and used with 4-fold cross validation method on the occurrence datasets prepared for S. denisonii and S. chalakkudiensis (Table 1 and Table 2) and environmental variables comprising climate, hydrology and topography (Table 3) for distribution modeling of these species as well as to estimate the presence probability of the species varying from 0 to 1 , where 0 is the lowest and 1 the highest probability (100\%). Sample radius of 5 pixels (150 meter) was used with $25 \%$ random test percentage for each replicate run.

\section{Results}

In this study, MaxEnt model predicted the potential niches and probability distribution maps of both $S$. denisonii and S. chalakkudiensi for the different river basins based on the known/reported occurrence records. The AUC (Area under Curve) for the two species are presented Fig. 1a and $b$ ). These figures indicate that the mean AUCs of the models of both the species are closed to 1 that proves that the models are good classifiers. The analysis reveals that 'Solar radiation' and 'Temperature' are the significant predictors for distribution of the species of the genus Sahyadria. The predictor permutation importance (\%) of the major predictors for distribution of both the species are presented (Fig. 2). This 
figure clearly shows that 'Temperature annual range' is the significant predictor variable followed by 'Solar radiation' in January and 'Temperature seasonality (standard deviation)' for distribution of $S$. denisonii. Further, 'Solar radiation' in April followed by 'Temperature annual range' and 'Temperature seasonality (standard deviation)' is the most significant predictor for distribution of S. chalakkudiensi. Though 'Slope steepness' and 'Logarithmic of accumulation' has low significance in the final model but AUCs get lowered if these predictors are dropped. This indicates that these predictors have some significance in finalizing the models of the species of genus Sahyadria. The jackknife test of these environmental variables showed that 'Temperature annual range', 'Solar radiation' and 'Temperature seasonality (standard deviation)' are the three important predictors for probable distribution of $S$. denisonii and S. chalakkudiensi. These variables presented the higher gain compared to other variables. In order to understand how long the species is likely to present in the rivers of different basins, the extent occurrence range of the species of genus Sahyadria for each class was calculated using the defined probability classes at the threshold of $>=0.5$ ( Table 4 and Table 5) and vector maps were published by converting the average value raster maps predicted for these two species (Fig. 3a and Fig. 3b) and analyzing the vector maps of these species at threshold of $>=0.5$ because at this threshold and above, the species is more likely to be present in the habitat(Fig. 4a and Fig. 4b). Further, to understand the phenomenon of distribution of the two species in response to the water flow, 'Precipitation' in the sub basin was determined as another significant climate envelope (Fig. 5). 
Table 4

Extent of probability distribution of Sahyadria denisonii predicted by the model using the occurrence records

\begin{tabular}{|c|c|c|c|c|c|}
\hline \multirow{3}{*}{$\begin{array}{l}\text { S. } \\
\text { No. }\end{array}$} & \multirow{3}{*}{$\begin{array}{l}\text { River system } \\
\text { (North to South) }\end{array}$} & \multicolumn{4}{|c|}{ Sahyadria denisonii } \\
\hline & & \multicolumn{2}{|c|}{$\begin{array}{l}\text { River length in } \\
\text { probability class } \\
\text { (in } \mathrm{Km} \text {.) }\end{array}$} & \multirow[t]{2}{*}{ Occurrence data used in study } & \multirow[t]{2}{*}{$\begin{array}{l}\text { Reported / } \\
\text { Remark }\end{array}$} \\
\hline & & $\begin{array}{l}50-75 \\
\%\end{array}$ & $\begin{array}{l}\text { Above } \\
75 \%\end{array}$ & & \\
\hline 1 & $\begin{array}{l}\text { Netravathi River } \\
\text { System }\end{array}$ & 255.6 & 103.72 & & $\begin{array}{l}\text { North of the } \\
\text { known } \\
\text { geographical } \\
\text { distribution }\end{array}$ \\
\hline 2 & $\begin{array}{l}\text { Payaswini River } \\
\text { System }\end{array}$ & 287.26 & 204.21 & $\begin{array}{l}\text { (John, 2009; John et al., 2013b; } \\
\text { Radhakrishnan, 2006) }\end{array}$ & $\begin{array}{l}\text { (Biju, 2003; } \\
\text { Kurup et al., } \\
2004 \text { ) }\end{array}$ \\
\hline 3 & $\begin{array}{l}\text { Karyangod River } \\
\text { System }\end{array}$ & 28.96 & 0.45 & (John, 2009) & $\begin{array}{l}\text { (Kurup and } \\
\text { Radhakrishnan, } \\
\text { 2006) }\end{array}$ \\
\hline 4 & $\begin{array}{l}\text { Thejaswini River } \\
\text { System }\end{array}$ & 153.1 & 90.09 & $\begin{array}{l}\text { (John et al., 2013b; } \\
\text { Radhakrishnan, 2006) }\end{array}$ & $\begin{array}{l}\text { Within the } \\
\text { range of the } \\
\text { known } \\
\text { geographical } \\
\text { distribution }\end{array}$ \\
\hline 5 & $\begin{array}{l}\text { Perumba River } \\
\text { System }\end{array}$ & 36.19 & 0 & & $\begin{array}{l}\text { Within the } \\
\text { range of the } \\
\text { known } \\
\text { geographical } \\
\text { distribution }\end{array}$ \\
\hline 6 & $\begin{array}{l}\text { Kuppam River } \\
\text { System }\end{array}$ & 75.12 & 43.13 & & $\begin{array}{l}\text { Within the } \\
\text { range of the } \\
\text { known } \\
\text { geographical } \\
\text { distribution }\end{array}$ \\
\hline 7 & $\begin{array}{l}\text { Kuttikkol puzha } \\
\text { River System }\end{array}$ & 10.66 & 0 & & $\begin{array}{l}\text { Within the } \\
\text { range of the } \\
\text { known } \\
\text { geographical } \\
\text { distribution }\end{array}$ \\
\hline 8 & $\begin{array}{l}\text { Bavali River } \\
\text { System }\end{array}$ & 744.07 & 289.96 & $\begin{array}{l}\text { (John, 2009; John et al., 2013b; } \\
\text { Radhakrishnan, 2006) }\end{array}$ & $\begin{array}{l}\text { Mercy, 2010; } \\
\text { Biju, 2005 }\end{array}$ \\
\hline 9 & $\begin{array}{l}\text { Anjarakandy puzha } \\
\text { River System }\end{array}$ & 70.7 & 2.33 & & $\begin{array}{l}\text { Within the } \\
\text { range of the } \\
\text { known } \\
\text { geographical } \\
\text { distribution }\end{array}$ \\
\hline
\end{tabular}




\begin{tabular}{|c|c|c|c|c|c|}
\hline \multirow{3}{*}{$\begin{array}{l}\text { S. } \\
\text { No. }\end{array}$} & \multirow{3}{*}{$\begin{array}{l}\text { River system } \\
\text { (North to South) }\end{array}$} & \multicolumn{4}{|c|}{ Sahyadria denisonii } \\
\hline & & \multicolumn{2}{|c|}{$\begin{array}{l}\text { River length in } \\
\text { probability class } \\
\text { (in } \mathrm{Km} \text {.) }\end{array}$} & \multirow[t]{2}{*}{ Occurrence data used in study } & \multirow[t]{2}{*}{$\begin{array}{l}\text { Reported / } \\
\text { Remark }\end{array}$} \\
\hline & & $\begin{array}{l}50-75 \\
\%\end{array}$ & $\begin{array}{l}\text { Above } \\
75 \%\end{array}$ & & \\
\hline 10 & Mahe River System & 60.41 & 48.49 & & $\begin{array}{l}\text { Within the } \\
\text { range of the } \\
\text { known } \\
\text { geographical } \\
\text { distribution }\end{array}$ \\
\hline 11 & $\begin{array}{l}\text { Kuttiadi River } \\
\text { System }\end{array}$ & 139.12 & 88.67 & & $\begin{array}{l}\text { (Kurup et al., } \\
2004)\end{array}$ \\
\hline 12 & $\begin{array}{l}\text { Korapuzha River } \\
\text { System }\end{array}$ & 31.03 & 18.47 & & $\begin{array}{l}\text { Within the } \\
\text { range of the } \\
\text { known } \\
\text { geographical } \\
\text { distribution }\end{array}$ \\
\hline 13 & $\begin{array}{l}\text { Akalapuzha River } \\
\text { System }\end{array}$ & 23.91 & 0 & & $\begin{array}{l}\text { Within the } \\
\text { range of the } \\
\text { known } \\
\text { geographical } \\
\text { distribution }\end{array}$ \\
\hline 14 & $\begin{array}{l}\text { Poonoor River } \\
\text { System }\end{array}$ & 40.29 & 16.8 & & $\begin{array}{l}\text { Within the } \\
\text { range of the } \\
\text { known } \\
\text { geographical } \\
\text { distribution }\end{array}$ \\
\hline 15 & $\begin{array}{l}\text { Chaliyar River } \\
\text { System }\end{array}$ & 558.88 & 176.49 & (John, 2009; John et al., 2013b) & $\begin{array}{l}\text { (Shaji et al., } \\
\text { 2000) }\end{array}$ \\
\hline 16 & $\begin{array}{l}\text { Kadalundi Puzha } \\
\text { River System }\end{array}$ & 161.17 & 115.17 & & $\begin{array}{l}\text { Within the } \\
\text { range of the } \\
\text { known } \\
\text { geographical } \\
\text { distribution }\end{array}$ \\
\hline 17 & $\begin{array}{l}\text { Bharathappuzha } \\
\text { River System / } \\
\text { PalGhat Gap } \\
\text { biogeographic } \\
\text { barrier }\end{array}$ & 864.64 & 436.29 & (Radhakrishnan, 2006) & $\begin{array}{l}\text { (Kurup et al., } \\
2004)\end{array}$ \\
\hline 18 & $\begin{array}{l}\text { Kurumali River } \\
\text { System }\end{array}$ & 101.59 & 64.87 & & $\begin{array}{l}\text { Within the } \\
\text { range of the } \\
\text { known } \\
\text { geographical } \\
\text { distribution }\end{array}$ \\
\hline
\end{tabular}




\begin{tabular}{|c|c|c|c|c|c|}
\hline \multirow{3}{*}{$\begin{array}{l}\text { S. } \\
\text { No. }\end{array}$} & \multirow{3}{*}{$\begin{array}{l}\text { River system } \\
\text { (North to South) }\end{array}$} & \multicolumn{4}{|c|}{ Sahyadria denisonii } \\
\hline & & \multicolumn{2}{|c|}{$\begin{array}{l}\text { River length in } \\
\text { probability class } \\
\text { (in } \mathrm{Km} \text {.) }\end{array}$} & \multirow[t]{2}{*}{ Occurrence data used in study } & \multirow[t]{2}{*}{$\begin{array}{l}\text { Reported / } \\
\text { Remark }\end{array}$} \\
\hline & & $\begin{array}{l}50-75 \\
\%\end{array}$ & $\begin{array}{l}\text { Above } \\
75 \%\end{array}$ & & \\
\hline 19 & $\begin{array}{l}\text { Chalakkudy River } \\
\text { System }\end{array}$ & 166.82 & 131.24 & $\begin{array}{l}\text { (John, 2009; John et al., 2013b; } \\
\text { Radhakrishnan, 2006) }\end{array}$ & $\begin{array}{l}\text { (Radhakrishnan } \\
\text { and Kurup, } \\
\text { 2006) }\end{array}$ \\
\hline 20 & $\begin{array}{l}\text { Periyar River } \\
\text { System }\end{array}$ & 1000 & 438.03 & $\begin{array}{l}\text { (John, 2009; John et al., 2013b; } \\
\text { Johnson and Arunachalam, } \\
\text { 2009; Radhakrishnan and } \\
\text { Kurup, 2006; Radhakrishnan, } \\
\text { 2006) }\end{array}$ & $\begin{array}{l}\text { (Thomas, } \\
\text { 2010) }\end{array}$ \\
\hline 21 & $\begin{array}{l}\text { Muvattupuzha } \\
\text { River System }\end{array}$ & 299.06 & 177.95 & & $\begin{array}{l}\text { Within the } \\
\text { range of the } \\
\text { known } \\
\text { geographical } \\
\text { distribution }\end{array}$ \\
\hline 22 & $\begin{array}{l}\text { Meenachal River } \\
\text { System }\end{array}$ & 168.5 & 87.55 & & $\begin{array}{l}\text { Within the } \\
\text { range of the } \\
\text { known } \\
\text { geographical } \\
\text { distribution }\end{array}$ \\
\hline 23 & $\begin{array}{l}\text { Manimala River } \\
\text { System }\end{array}$ & 105.51 & 79.88 & & $\begin{array}{l}\text { (Thomas, } \\
\text { 2010) }\end{array}$ \\
\hline 24 & $\begin{array}{l}\text { Pampa River } \\
\text { System }\end{array}$ & 194.74 & 214.42 & $\begin{array}{l}\text { (John et al., 2013b; Kurup and } \\
\text { Radhakrishnan, 2006) }\end{array}$ & $\begin{array}{l}\text { (Thomas, } \\
\text { 2010) }\end{array}$ \\
\hline 25 & $\begin{array}{l}\text { Achenkoil River } \\
\text { System }\end{array}$ & 192.56 & 139.31 & (Radhakrishnan, 2006) & $\begin{array}{l}\text { (Kurup et al., } \\
2004)\end{array}$ \\
\hline 26 & $\begin{array}{l}\text { Kallada River } \\
\text { System }\end{array}$ & 271.98 & 136.72 & & $\begin{array}{l}\text { South of the } \\
\text { known } \\
\text { geographical } \\
\text { distribution }\end{array}$ \\
\hline 27 & $\begin{array}{l}\text { Ithikkara River } \\
\text { System }\end{array}$ & 124.03 & 110.32 & & $\begin{array}{l}\text { South of the } \\
\text { known } \\
\text { geographical } \\
\text { distribution }\end{array}$ \\
\hline 28 & $\begin{array}{l}\text { Vamanapuram } \\
\text { River System }\end{array}$ & 111.26 & 86.68 & & $\begin{array}{l}\text { South of the } \\
\text { known } \\
\text { geographical } \\
\text { distribution }\end{array}$ \\
\hline
\end{tabular}




\begin{tabular}{|c|c|c|c|c|c|}
\hline \multirow{3}{*}{$\begin{array}{l}\text { S. } \\
\text { No. }\end{array}$} & \multirow{3}{*}{$\begin{array}{l}\text { River system } \\
\text { (North to South) }\end{array}$} & \multicolumn{4}{|c|}{ Sahyadria denisonii } \\
\hline & & \multicolumn{2}{|c|}{$\begin{array}{l}\text { River length in } \\
\text { probability class } \\
\text { (in Km.) }\end{array}$} & \multirow[t]{2}{*}{ Occurrence data used in study } & \multirow[t]{2}{*}{$\begin{array}{l}\text { Reported / } \\
\text { Remark }\end{array}$} \\
\hline & & $\begin{array}{l}50-75 \\
\%\end{array}$ & $\begin{array}{l}\text { Above } \\
75 \%\end{array}$ & & \\
\hline 29 & $\begin{array}{l}\text { Karamana River } \\
\text { System }\end{array}$ & 77.14 & 55.16 & & $\begin{array}{l}\text { South of the } \\
\text { known } \\
\text { geographical } \\
\text { distribution }\end{array}$ \\
\hline 30 & $\begin{array}{l}\text { Neyyar River } \\
\text { System }\end{array}$ & 57.99 & 45.07 & & $\begin{array}{l}\text { South of the } \\
\text { known } \\
\text { geographical } \\
\text { distribution }\end{array}$ \\
\hline 31 & $\begin{array}{l}\text { Thamiraparani } \\
\text { River System }\end{array}$ & 37.03 & 38.04 & & $\begin{array}{l}\text { South of the } \\
\text { known } \\
\text { geographical } \\
\text { distribution }\end{array}$ \\
\hline
\end{tabular}

Table5 Extent of probability distribution of Sahyadria chalakkudiensis predicted by the model using the occurrence records 


\begin{tabular}{|c|c|c|c|c|c|}
\hline \multirow{3}{*}{$\begin{array}{l}\text { S. } \\
\text { No. }\end{array}$} & \multirow{3}{*}{$\begin{array}{l}\text { River system (North to } \\
\text { South) }\end{array}$} & \multicolumn{4}{|c|}{ Sahyadria chalakkudiensis } \\
\hline & & \multicolumn{2}{|c|}{$\begin{array}{l}\text { River length in } \\
\text { probability class } \\
\text { (in } \mathrm{Km} \text {.) }\end{array}$} & \multirow[t]{2}{*}{$\begin{array}{l}\text { Occurrence data } \\
\text { used in study }\end{array}$} & \multirow[t]{2}{*}{ Reported / Remark } \\
\hline & & $\begin{array}{l}50-75 \\
\%\end{array}$ & $\begin{array}{l}\text { Above } \\
75 \%\end{array}$ & & \\
\hline 1 & $\begin{array}{l}\text { Bharathappuzha River } \\
\text { System / PalGhat Gap } \\
\text { biogeographic barrier }\end{array}$ & 145.61 & 46.6 & & $\begin{array}{l}\text { North of the known } \\
\text { geographical } \\
\text { distribution }\end{array}$ \\
\hline 2 & Kurumali River System & 27.31 & 0 & & $\begin{array}{l}\text { North of the known } \\
\text { geographical } \\
\text { distribution }\end{array}$ \\
\hline 3 & Chalakkudy River System & 34.58 & 38.31 & $\begin{array}{l}\text { (John et al., } \\
\text { 2013b; Menon et } \\
\text { al., 1999) }\end{array}$ & \\
\hline 4 & Periyar River System & 153.07 & 150.91 & $\begin{array}{l}\text { (John et al. } \\
2013 \text { ) }\end{array}$ & \\
\hline 5 & $\begin{array}{l}\text { Muvattupuzha River } \\
\text { System }\end{array}$ & 99.52 & 87.84 & & $\begin{array}{l}\text { Within the range of } \\
\text { the known } \\
\text { geographical } \\
\text { distribution }\end{array}$ \\
\hline 6 & Meenachal River System & 65.89 & 52.63 & & $\begin{array}{l}\text { Within the range of } \\
\text { the known } \\
\text { geographical } \\
\text { distribution }\end{array}$ \\
\hline 7 & Manimala River System & 27.37 & 63.89 & & $\begin{array}{l}\text { Within the range of } \\
\text { the known } \\
\text { geographical } \\
\text { distribution }\end{array}$ \\
\hline 8 & Pampa River System & 99.07 & 136.47 & $\begin{array}{l}\text { (Arunachalam et } \\
\text { al., 2013; John et } \\
\text { al., 2013b) }\end{array}$ & \\
\hline 9 & Achenkoil River System & 96.42 & 125.01 & $\begin{array}{l}\text { (Baby et al., } \\
\text { 2011) }\end{array}$ & \\
\hline 10 & Kallada River System & 85.33 & 85.39 & & $\begin{array}{l}\text { South of the known } \\
\text { geographical } \\
\text { distribution }\end{array}$ \\
\hline 11 & Ithikkara River System & 33.82 & 70.24 & & $\begin{array}{l}\text { South of the known } \\
\text { geographical } \\
\text { distribution }\end{array}$ \\
\hline
\end{tabular}

\section{Discussion}


The spatial predicted distribution model was developed for the two important fish species $S$. denisonii and $S$. chalakkudiensi in the Western ghat ecosystem and priority ecological niche forecasted relating the relative contribution of bioclimatic features. Though in inland waters few models were reported in fisheries (Panikker and Khan, 2008; Khan, 2015; Sarkar, 2019 and 2021), however, this is the first attempt which predicted the geographical distribution of an important species in relation of environmental and climatological dataset. The pattern of distribution range under seasonality was noticed and depicted. The distribution range difference was noticed between the two species especially during the monsoon season from May to September and further as indicated in Fig. 5 priority habitat distribution of $S$. denisonii were modelled in higher precipitation area compared to $S$. chalakkudiensi. The results derived from the models shows that distribution of $S$. denisonii majorly depends on the 'Temperature Annual Range', 'Temperature Seasonality', 'Solar radiation' in January and 'Slope' of the river. These are somewhat important predictors in defining the ecological niche of this species. Similarly, 'Solar Radiation' in April, 'Temperature Annual Range', 'Temperature Seasonality' and 'Logarithmic of the accumulation' are the important environmental factors in defining the ecological niche of $S$. chalakkudiensis. The Jackknife test further provide more information about these predictors suggesting that 'Temperature' and 'Solar radiation' in January and December are the limiting factors in distribution of $S$. denisonii because these months are breeding periods of this species with peak Gonado Somatic Index (GSI) (Solomon et al., 2011). Similarly, 'Solar radiation' and 'Temperature' in January as well as February are critical for distribution of $S$. chalakkudiensis associated with breeding of this species during these months. Thus, in totality, 'Temperature' and 'Solar radiation' were found as the important predictors for distribution of species of the genus Sahyadria and among variables these are significant variable for providing the ecological niche of the species of this genus. In case of $S$. denisonii though 'Logarithmic of accumulation (log accumulation)' itself has not much permutation importance $(0.6723 \%)$ but removal of it from the list of predictors causes AUC to drop significantly suggesting that it has some relevance. Genus Sahyadria is distributed in 14 small rivers in the Western Ghats (John et al., 2013b) of which S. denisonii is found in its entire latitudinal distribution. Our models at the latitudinal scale suggests that there are some other rivers, which have suitable ecological niche for $S$. denisonii in small fragments, but the rivers Netravati, Kallada and Ithikkara are completely suitable. Thus, it is interesting to know that whether $S$. denisonii is occurring there or the ecological niche is occupied by other species. The model also suggests that the river Periyar has more occurrence probabilities for $S$. chalakkudiensis than the river Chalakkudi.

The probability distribution model of the species of genus Sahyadria indicates that Palghat Gap is a barrier in the distribution as reported (John et al., 2013a). It is due to distinct lineages in this genus and 8 distinct genetic lineages have been reported in this genus so far (John et al., 2013b) and if grouped in two clades then one clade is comprising populations north of Palghat and the other south of it. The population in both the clades differs in size, body shape and colour and indicates that Palghat Gap is a barrier in the distribution (John et al., 2013a). Subsequently, the model suggests that southernmost distribution of ecological niche for north Kerala population lies in the river Aylampuzha and Mangalam, which are tributaries of the river Bharathapuzha. However, for detailed understanding of distribution of all lineages, there is a need to collect more detailed environmental data of microhabitat, for all lineages. In 
the present study, only air temperature as a predictor has been used because of its adequate availability of information which is an important predictor according to the models. The relationship of air with water temperature is not always linear therefore, it is important to have data on water temperature from its known range of distribution for more detailed mapping.

\section{Conclusion}

The spatial distribution model developed for the species of the genus Sahyadria showed good performance in a wide range of environmental situations. The present study depicts suitable ecological niches offering distribution of the species and factors affecting the distribution. However, output of the model for understanding the distribution of all the lineages can be enhanced by including more climatoenvironmental data supported by microhabitat and fish assemblage pattern for all lineages, water temperature and threats from its known range of distribution. The information generated is highly relevant to both space and time. The probability distribution map presenting the details on ecological niche can help in land use management around its existing populations, discover new populations, identify top priority survey sites as well as set priorities to restore its natural habitat for more effective conservation. The methodology conceptualized and demonstrated here could be used for determining the ecological niches for other threatened and endangered plant and animal species in other potential areas and may aid in the field surveys and setting up the conservation and restoration efforts by the managers and stakeholders of natural resources.

\section{Declarations}

\section{a. Ethics approval and consent to participate}

Not applicable as the study does not use any animal.

\section{b. Consent for publication}

Not applicable as the manuscript does not contain the data from any individual person.

\section{c. Availability of data and materials}

All data generated or analyzed during this study are included in this published article.

\section{d. Competing interest}

The authors declare that they have no competing interests.

\section{e. Funding}

Not applicable as no funding support has been granted by any external funding agency to complete this study. 


\section{f. Authors' contribution}

Ajey Kumar Pathak (AKP) conceptualized the idea and checked the data, maps and models for authecity and accuracy. AKP drafted and edited the manuscript. Pushpendra Verma downloaded the data and MaxEnt software. He configured the software under Linux operating system for working and analyzed the data (occurrence and environmental) using MaxEnt. All the GIS analysis was done by him and the resultant maps were too produced by him the QGIS software. Rajesh Dayal (RD) collected the occurrence data of fish species used in the study and assisted in verifying the predicted distribution of fish species using literature. Uttam Kumar Sarkar (UKS) edited the manuscript and suggested this journal for publication of this article.

\section{Acknowledgement}

Authors are thankful to Director, ICAR- National Bureau of Fish Genetic Resources for providing necessary facilities for accomplishment of the work under study.

\section{References}

1. Ali A, Raghavan R, Dahanukar N (2015) Sahyadria denisonii. The IUCN Red List of Threatened Species 2015: e. T169662A70082469.

2. Allan JD, Flecker AS (1993) Biodiversity conservation in running waters. BioScience 43(1): 32-43.

3. Arunachalam M, Raja M, Nandagopal S, Chandran A (2013) Range Extension of an Endemic Ornamental Fish Species Puntius chalakkudiensis from Southern Kerala River Research and Reviews. Journal of Zoological Sciences 2: 20-24.

4. Austin M (2007) Species distribution models and ecological theory: a critical assessment and some possible new approaches. Ecological modelling 200: 1-19.

5. Baby F, Tharian J, Philip S, Ali A, Raghavan R (2011) Checklist of the fishes of the Achankovil forests, Kerala, India with notes on the range extension of an endemic cyprinid Puntius chalakkudiensis. Journal of Threatened Taxa 3(7): 1936-1941.

6. Benito BM, Martínez-Ortega MM, Munoz L M, Lorite J, Penas J (2009) Assessing extinction-risk of endangered plants using species distribution models: a case study of habitat depletion caused by the spread of greenhouses. Biodiversity and Conservation 18: 2509-2520.

7. Biju CR (2003) Habitat and distribution of hill stream fishes of Northern Kerala (North of Palghat Gap). PhD Thesis. Department of Zoology, Mahatma Gandhi University, 146pp.

8. Buisson L, Thuiller W, Lek S, Lim P, Grenouillet G (2008) Climate change hastens the turnover of stream fish assemblages. Global Change Biology 14(10): 2232-2248. https://doi.org/10.1111/j.1365-2486.2008.01657.x.

9. Chefaoui RM, Lobo JM (2008) Assessing the effects of pseudo-absences on predictive distribution model performance. Ecological modelling 210(4): 478-486. 
10. Dayal R, Singh SP, Sarkar UK, Pandey AK, Pathak AK, Chaturvedi R (2014) Fish Biodiversity of Western Ghats Region of India: A Review. Journal of experimental zoology17: 377-399.

11. Ehlschlaeger CR (1989) Using the $A^{\wedge} T$ search algorithm to develop hydrologic models from digital elevation data, in: Proceedings of the International Geographic Information System (IGIS) Symposium, Baltimore, MD. 275pp.

12. Elith J, Graham CH, Anderson RP, Dudík M, Ferrier S, Guisan A, Hijmans RJ, Huettmann F, Leathwick JR, Lehmann A, Li J,.Lohmann LG, Loiselle BA, Manion G, Moritz C, Nakamura M, Nakazawa Y, Overton JMM,. Peterson AT, Phillips SJ, Richardson K, Scachetti- Pereira R, Schapire RE, Soberón J, Williams S, Wisz MS, Zimmermann NE (2006) Novel methods improve prediction of species distributions from occurrence data. Ecography 29:129-151. https://doi.org/10.1111/j.2006.09067590.04596.x.

13. Fick, SE, Hijmans RJ (2017) WorldClim 2: new 1-km spatial resolution climate surfaces for global land areas. International journal of climatology 37(12): 4302-4315.

14. Franklin J (2010) Mapping species distributions: spatial inference and prediction. Cambridge University Press, Cambridge, 319pp.

15. Graham CH, Ron SR, Santos JC, Schneider CJ, Moritz C (2004) Integrating phylogenetics and environmental niche models to explore speciation mechanisms in dendrobatid frogs. Evolution 58(8): $1781-1793$.

16. Guisan A, Tingley R, Baumgartner JB, Naujokaitis- Lewis I, Sutcliffe PR, Tulloch AIT, Regan TJ, Brotons L, McDonald- Madden E, Mantyka- Pringle C, Martin TG, Rhodes JR, Maggini R, Setterfield SA, Elith J, Schwartz MW, Wintle BA, Broennimann O, Austin M, Ferrier S, Kearney MR, Possingham HP, Buckley YM (2013) Predicting species distributions for conservation decisions. Ecology letters 16(12): 1424-1435. https://doi.org/10.1111/ele.12189.

17. Hernandez PA, Franke I, Herzog SK, Pacheco V, Paniagua L, Quintana H, Soto A, Swenson JJ, Tovar C, Valqui TH (2008) Predicting species distributions in poorly-studied landscapes. Biodiversity and conservation, 17(6): 1353-1366.

18. Hernandez PA, Graham CH, Master LL, Albert DL (2006) The effect of sample size and species characteristics on performance of different species distribution modelling methods. Ecography 29:773-785.

19. John L (2009) Population genetic structure of indigenous ornamental teleosts, Puntius denisonii and Puntius chalakkudiensis from the Western Ghats, India (PhD Thesis). Central Marine Fisheries Research Institute.

20. John L, Peter R, Gopalakrishnan A (2013a) Population structure of Denison's barb, Puntius denisonii (Pisces: Cyprinidae): a species complex endemic to the Western Ghats of India. Journal of Phylogenetics and Evolutionary Biology: 1-12.

21. John L, Philip S, Dahanukar N, Ali A, Tharian J, Raghavan R, Antunes A (2013b) Morphological and genetic evidence for multiple evolutionary distinct lineages in the endangered and commercially 
exploited red lined torpedo barbs endemic to the Western Ghats of India. PloS One 8(7): e69741. https://doi.org/10.1371/journal.pone.0069741.

22. Johnson JA, Arunachalam M (2009) Diversity, distribution and assemblage structure of fishes in streams of southern Western Ghats, India. Journal of Threatened Taxa: 507-513.

23. Khan, MF, Preetha, P, Sharma, AP (2015) Modelling the food web for assessment of the impact of stock supplementation in a reservoir ecosystem in India. Fisheries Management and Ecology 22 (5): 359-370.

24. Kramer Schadt S, Niedballa J, Pilgrim JD, Schröder B, Lindenborn J, Reinfelder V, Stillfried M, Heckmann I, Scharf AK, Augeri DM, Cheyne SM (2013) The importance of correcting for sampling bias in MaxEnt species distribution models. Diversity and Distributions 19(11), pp.1366-1379.

25. Kurup BM, Radhakrishnan KV (2006) Indigenous ornamental fish resources of Western Ghats with special reference to Kerala, in: Souvenir of Ornamentals Kerala 2006, International Seminar on Ornamental Fish Breeding, Farming and Trade. Department of Fisheries, Government of Kerala, Cochin, India.

26. Kurup BM, Radhakrishnan KV, Manojkumar TG (2004) Biodiversity status of fishes inhabiting rivers of Kerala (S. India) with special reference to endemism, threats and conservation measures, in Proceedings of LARS2. 2nd Large Rivers Symposium. Mekong River Commission and Food and Agricultural Organization 163-182.

27. Lanczos C (1938) Trigonometric interpolation of empirical and analytical functions. Journal of Mathematics and Physics 17: 123-199.

28. Lobo JM, Jiménez-Valverde A, Real R (2008) AUC: a misleading measure of the performance of predictive distribution models. Global ecology and Biogeography 17(2), 145-151.

29. Maloney KO, Mitchell RM, Feminella, JW (2006) Influence of catchment disturbance on Pteronotropis euryzonus (Broadstripe shiner) and Semotilus thoreauianus (Dixie chub). Southeastern Naturalist, 5(3): 393-412.

30. McCool DK, Brown LC, Foster GR, Mutchler KC, Meyer, LD (1987) Revised slope steepness factor for the Universal Soil Loss Equation. Transactions of the ASAE, 30(5): 1387-1396.

31. McKinney ML, Lockwood JL (1999) Biotic homogenization: a few winners replacing many losers in the next mass extinction. Trends in ecology \& evolution 14(11): 450-453.

32. Mcnyset K (2005) Use of ecological niche modelling to predict distributions of freshwater fish species in Kansas. Ecology of Freshwater Fish, 14(3): 243-255. https://doi.org/10.1111/j.16000633.2005.00101.x.

33. Menon AGK, Devi KR, Thobias MP (1999) Puntius chalakkudiensis, a new colourful species of Puntius (family: Cyprinidae) fish from Kerala, south India. Records of the Zoological Survey of India, 97(4): 61-63.

34. Moore ID, Grayson RB, Ladson AR (1991) Digital terrain modelling: a review of hydrological, geomorphological, and biological applications. Hydrological processes 5(1): 3-30. 
35. Oakes, RM, Gido KB, Falke JA, Olden JD, Brock BL (2005) Modelling of stream fishes in the Great Plains, USA. Ecology of Freshwater Fish, 14(4): 361-374. https://doi.org/10.1111/j.16000633.2005.00110.x.

36. Panikkar P., Khan M.F. 2008 Comparative mass balanced trophic models to assess the impact of environmental management measures in a tropical reservoir ecosystem. Ecological Modelling 212:280-291.

37. Papeş $M$, Gaubert $P$ (2007) Modelling ecological niches from low numbers of occurrences: assessment of the conservation status of poorly known viverrids (Mammalia, Carnivora) across two continents. Diversity and distributions, 13(6): 890-902.

38. Pearson RG (2007) Species distribution modelling for conservation educators and practitioners. Synthesis. American Museum of Natural History 50: 54-89.

39. Phillips SJ, Dudík M, Schapire RE (2004) A maximum entropy approach to species distribution modelling, in: Proceedings of the Twenty-First International Conference on Machine Learning, 83pp.

40. Pittman SJ, Brown KA (2011) Multi-scale approach for predicting fish species distributions across coral reef seascapes. PloS One 6(5). e20583. https://doi.org/10.1371/journal.pone.0020583.

41. Quinn P, Beven KP, Chevallier, Planchon O (1991) The prediction of hillslope flow paths for distributed hydrological modelling using digital terrain models. Hydrological processes, 5(1): 59-79. https://doi.org/10.1002/hyp.3360050106.

42. Radhakrishnan KV (2006) Systematics, Germplasm evaluation and pattern of distribution and abundance of freshwater fishes of Kerala (India) (PhD Thesis). Cochin University of Science and Technology.

43. Radhakrishnan KV, Kurup BM (2006) Distribution and stock size of freshwater ornamental fishes of Kerala (S India) with special reference to sustainability issue, in: Sustain Fish-International Symposium on Improved Sustainability of Fish Production Systems and Appropriate Technologies for Utilization, 589-605.

44. Raghavan R, Ali A, Philip S, Dahanukar N (2018) Effect of unmanaged harvests for the aquarium trade on the population status and dynamics of redline torpedo barb: a threatened aquatic flagship. Aquatic Conservation: Marine and Freshwater Ecosystems, 28(3): 567-574.

45. Raghavan R, Dahanukar N, Tlusty MF, Rhyne AL, Kumar KK, Molur S, Rosser AM (2013). Uncovering an obscure trade: threatened freshwater fishes and the aquarium pet markets. Biologica Conservation164: 158-169.

46. Rahel FJ (2002) Homogenization of freshwater faunas. Annual review of ecology and systematics 33(1): 291-315.

47. Rose PM, Kennard MJ, Sheldon F, Moffatt DB, Butler GL (2016) A data-driven method for selecting candidate reference sites for stream bioassessment programs using generalised dissimilarity models. Marine and Freshwater Research, 67(4): 440-454.

48. Sarkar U K, Roy K, Naskar M, Srivastava PK, Bose AK, Verma VK, Gupta S, Nandy SK, Sarkar SD, Karnatak G, Sudheesan D, Das BK (2019) Minnows may be more reproductively resilient to climatic 
variability than anticipated: Synthesis from a reproductive vulnerability assessment of Gangetic pool barbs (Puntius sophore). Ecological Indicators.105:727-736.

49. Sarkar, U.K., Roy, K., Karnatak, G., Naskar, M., Puthiyottil, M., Baksi, S., Lianthuamluaia, L., Kumari, S., Ghosh, B.D. and Das, BK (2021) Reproductive environment of the decreasing Indian river shad in Asian inland waters: disentangling the climate change and indiscriminative fishing threats. Environmental Science and Pollution Research, doi:10.1007/s11356-021-12852-7.

50. Schleiger SL (2000) Use of an index of biotic integrity to detect effects of land uses on stream fish communities in west-central Georgia. Transactions of the American Fisheries Society 129(5): 11181133.

51. Schlosser IJ (1982) Fish community structure and function along two habitat gradients in a headwater stream. Ecological monographs 52(4): 395-414.

52. Shaji CP, Easa PS, Gopalakrishnan A (2000) Freshwater fish diversity of Western Ghats. Endemic Fish Diversity of Western Ghats. NBFGR-NATP publication, National Bureau of Fish Genetic Resources, Lucknow, India, 347pp.

53. Soberon J, Peterson AT (2005) Interpretation of models of fundamental ecological niches and species' distributional areas. Biodiversity Informatics 2: 1-10.

54. Solomon S, Ramprasanth MR, Baby F, Pereira B, Tharian J, Ali A, Raghavan R (2011) CEPF Western Ghats Special Series: Reproductive biology of Puntius denisonii, an endemic and threatened aquariumfish of the Western Ghats and its implications for conservation. Journal of Threatened Taxa, 3(9): 2071-2077. https://doi.org/10.11609/JoTT.o2608.2071-7.

55. Thomas R (2010) Habitat and distribution of hill stream fishes of Southern Kerala (south of palghat gap). PhD Thesis. Department of Zoology, Mahatma Gandhi University, 240pp.

56. Weltz MA, Renard KG, Simanton, JR (1987) Revised Universal Soil Loss Equation for Western Rangelands. General Technical Report RM-150, US Department of Agriculture, 104 pp.

57. Wisz MS, Hijmans RJ, Li J, Peterson AT, Graham CH, Guisan A, (2008) Predicting Species Distributions Working Group, 2008. Effects of sample size on the performance of species distribution models. Diversity and distributions 14(5): 763-773.

\section{Figures}




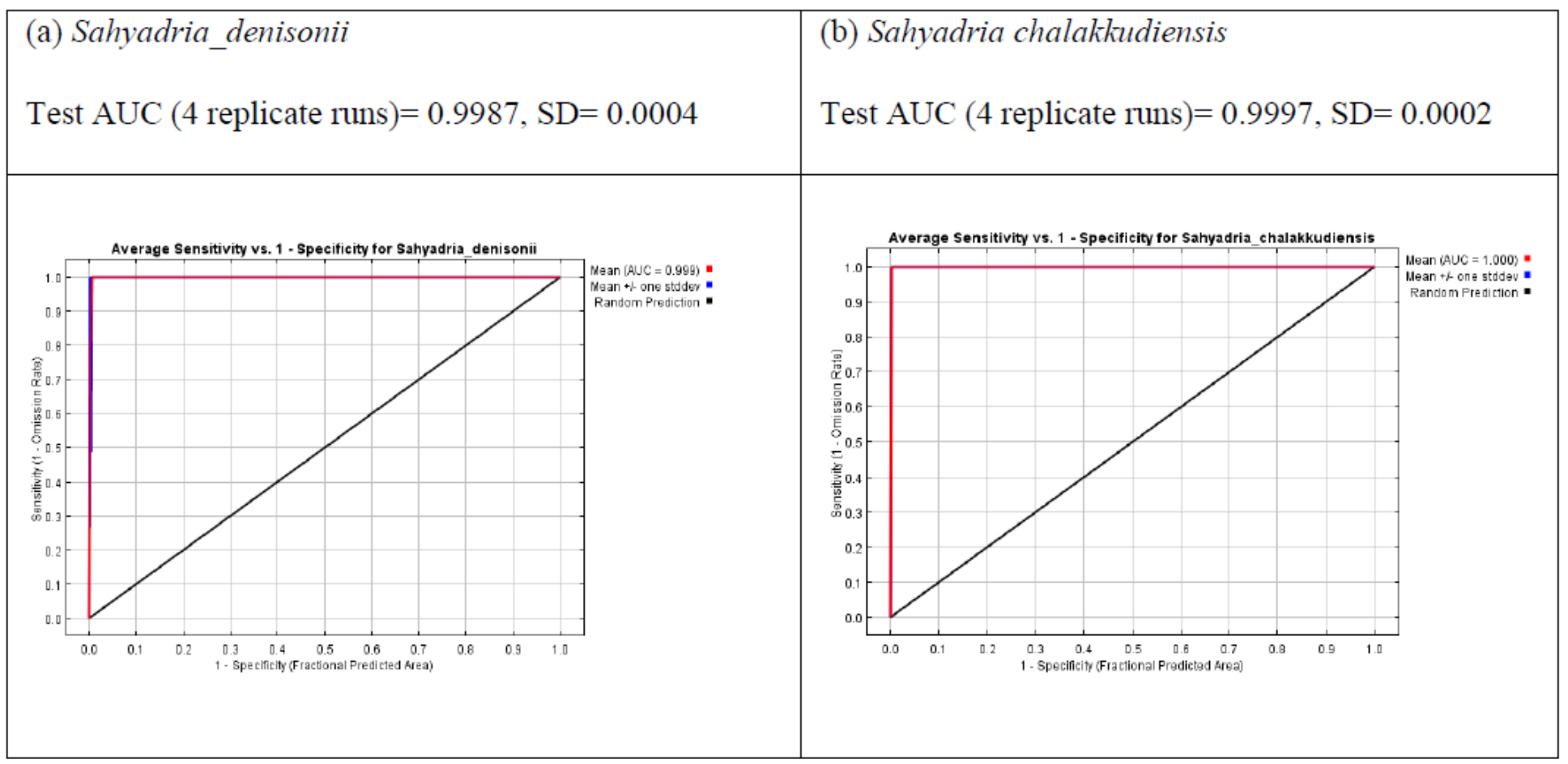

\section{Figure 1}

( $a$ and $b$ ). Area under curve (AUC) between average sensitivity and specificity for the species of Genus Sahyadria 


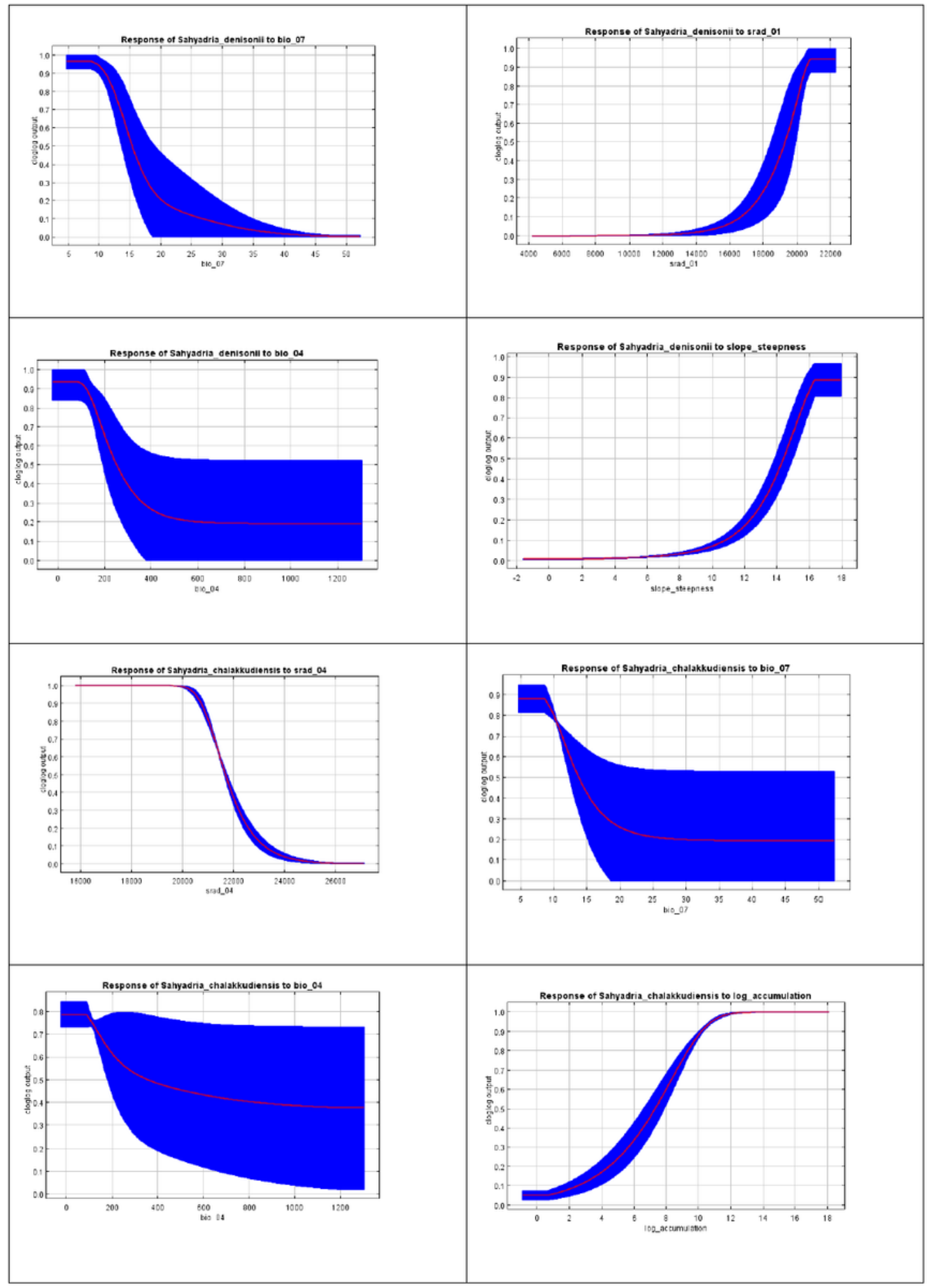

Figure 2

Important predictor variables and their response curve for Sahyadria denisonii and Sahyadria chalakkudiensis with their permutation importance in \% (average of 4 replicate runs). In each graph Xaxis represents prediction probabilities between 0 (Absent) and 1 (100\% present). Sahyadria denisonii: bio_07 (63.0941\%), srad_01 (14.7454\%), bio_04 (13.7885\%), slope_steepness (7.0731\%) Sahyadria chalakkudiensis: srad_04 (39.644 \%), bio_07 (25.28 \%), bio_04 (20.2391 \%), log_accumulation (5.7099 \%) 


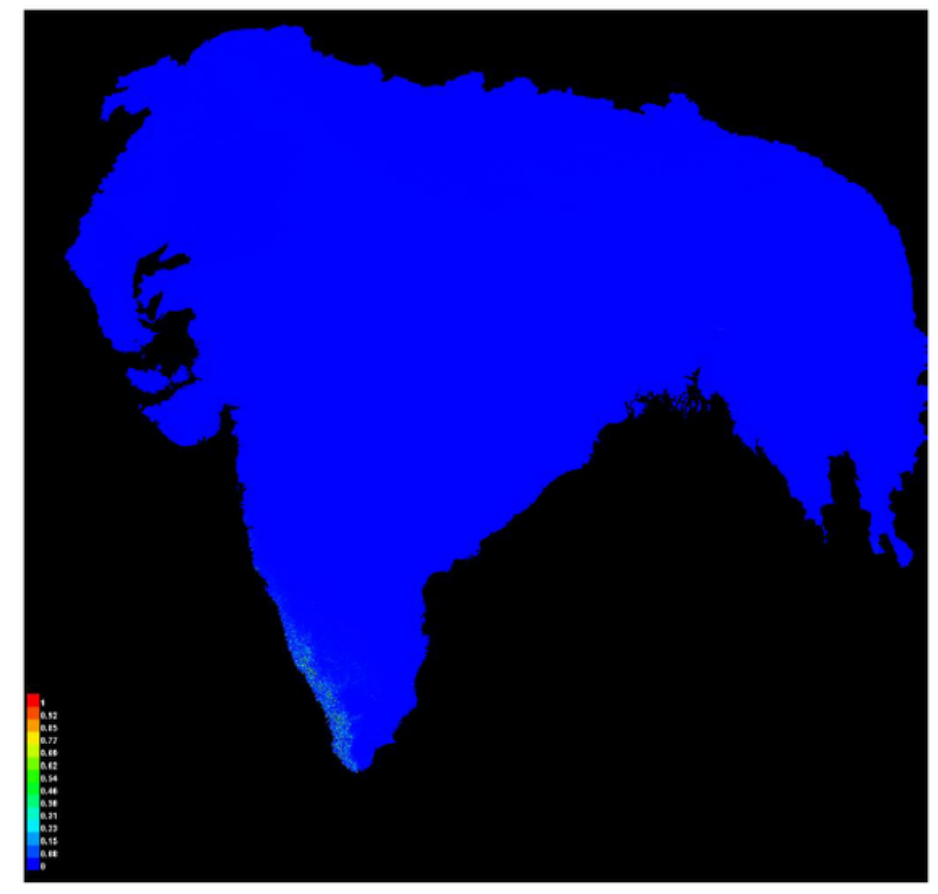

(a)

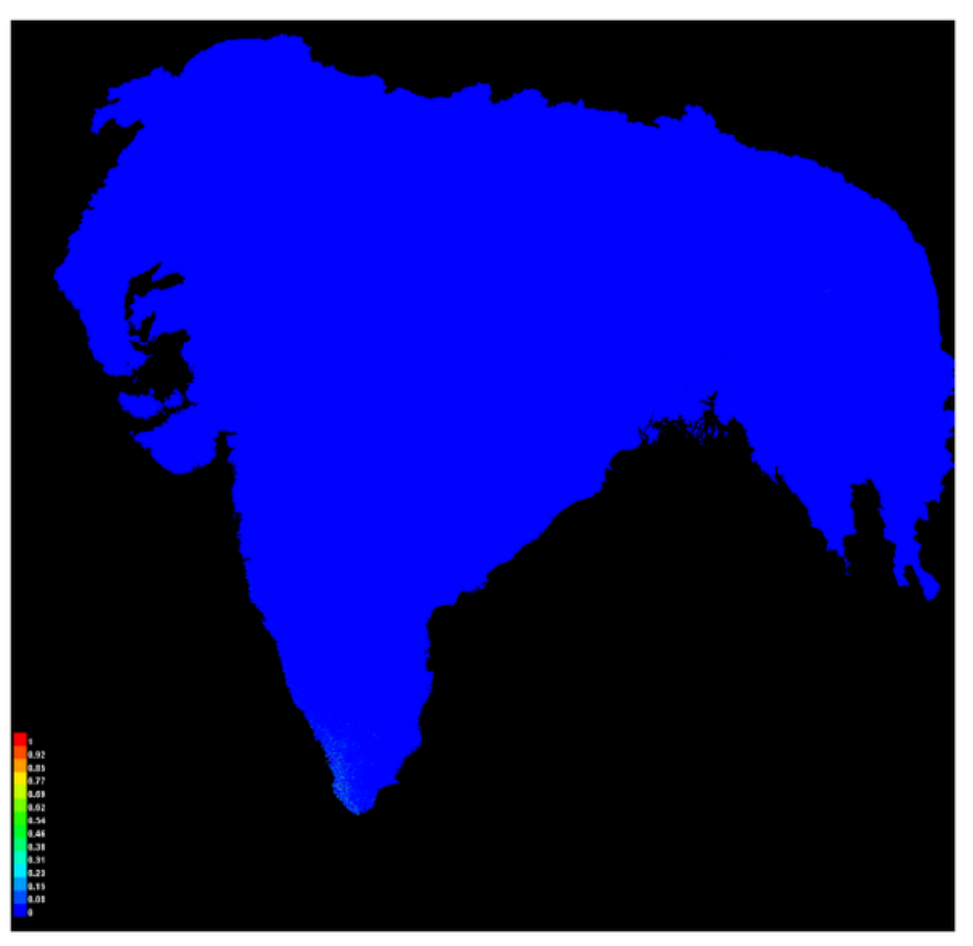

(b)

\section{Figure 3}

a Average values raster maps of Sahyadria denisonii predicted by the model b Average values raster maps of Sahyadria chalakkudiensis predicted by the model Note: The designations employed and the presentation of the material on this map do not imply the expression of any opinion whatsoever on the part of Research Square concerning the legal status of any country, territory, city or area or of its authorities, or concerning the delimitation of its frontiers or boundaries. This map has been provided by the authors. 


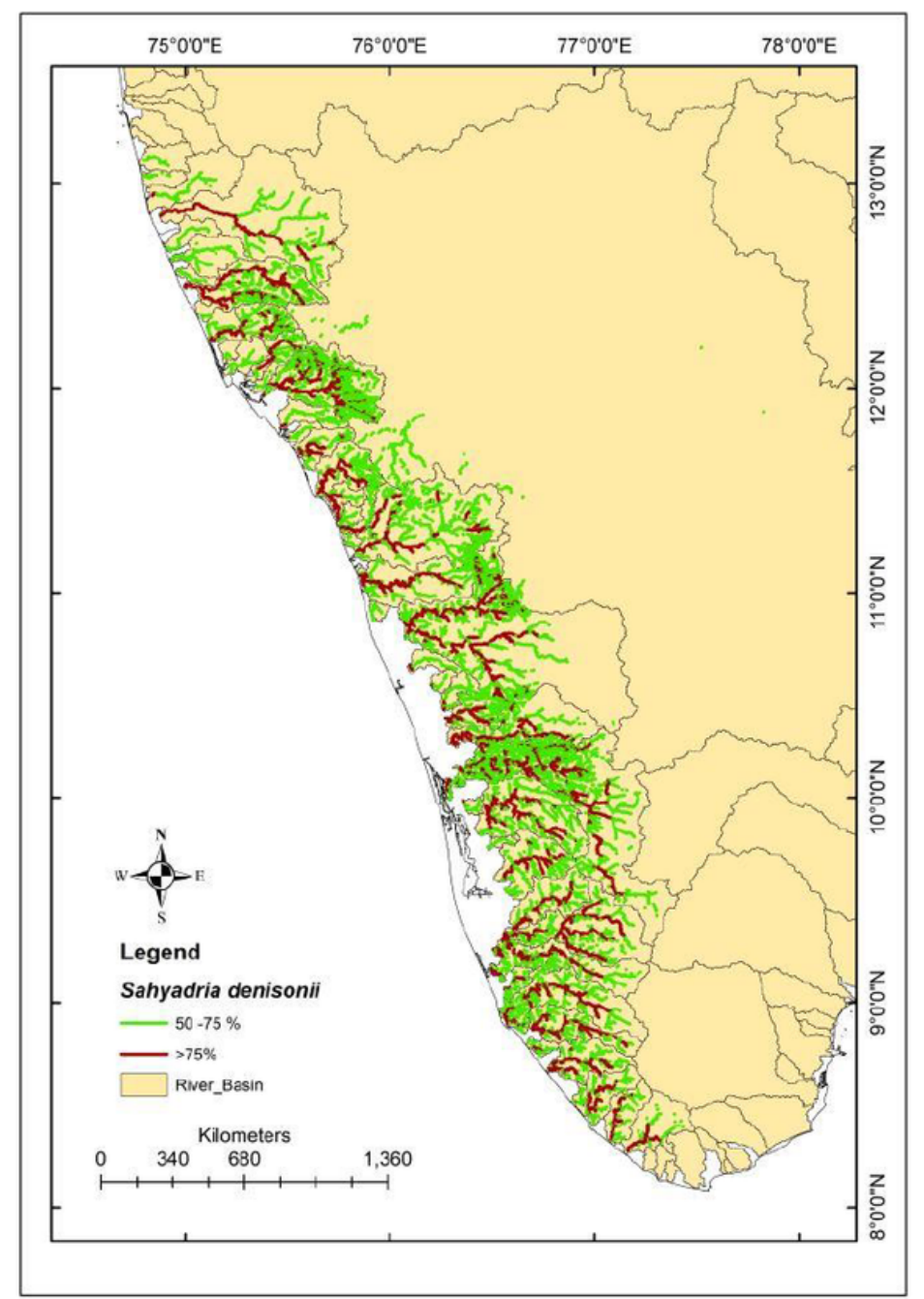

(a)

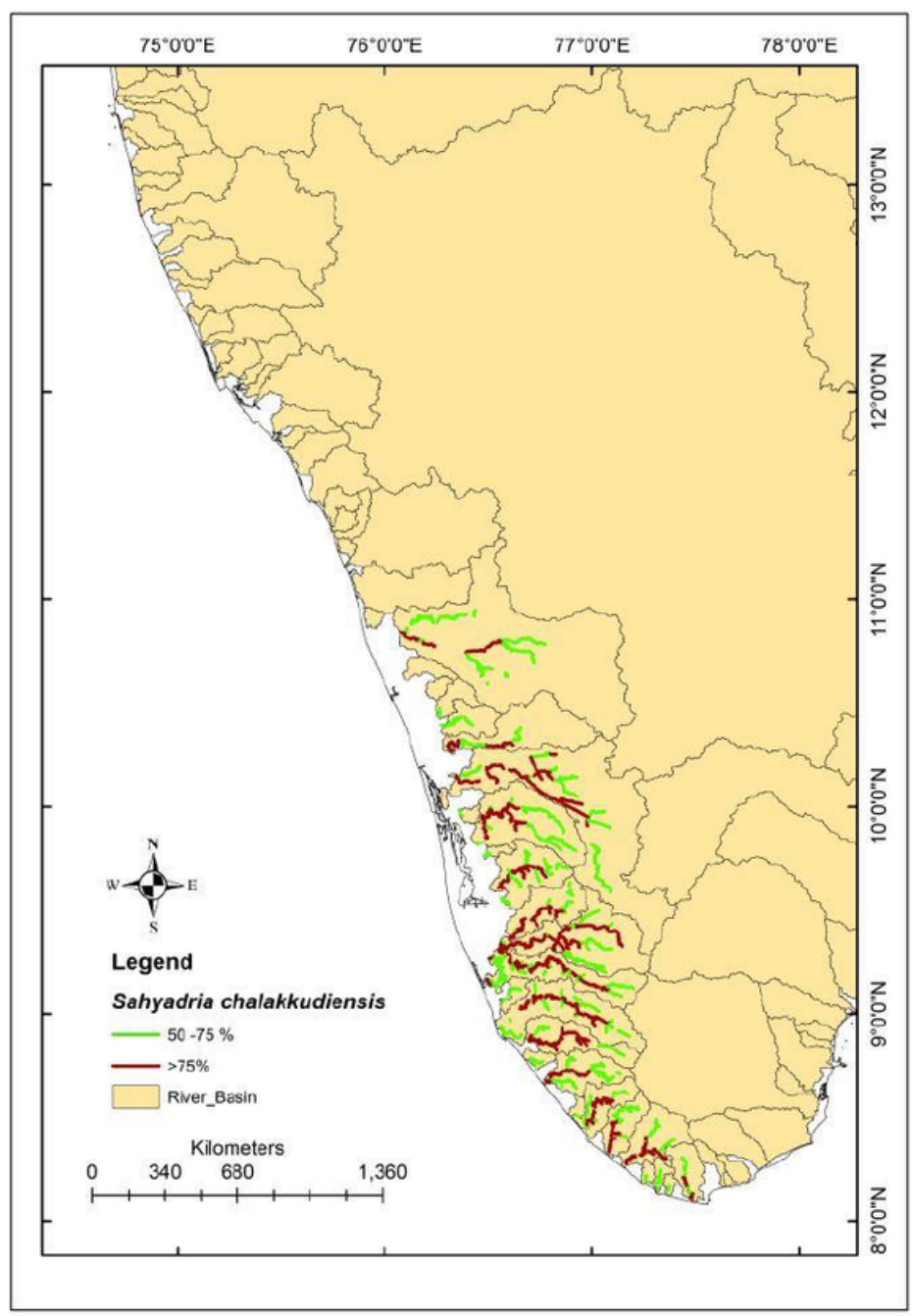

(b)

\section{Figure 4}

a Predicted distribution of Sahyadria denisonii in the Western Ghats derived from predicted raster map at threshold of $>=0.5 \mathrm{~b}$ Predicted distribution of Sahyadria chalakkudiensis in the Western Ghats derived from predicted raster map at threshold of $>=0.5$ Note: The designations employed and the presentation of the material on this map do not imply the expression of any opinion whatsoever on the part of Research Square concerning the legal status of any country, territory, city or area or of its authorities, or concerning the delimitation of its frontiers or boundaries. This map has been provided by the authors. 


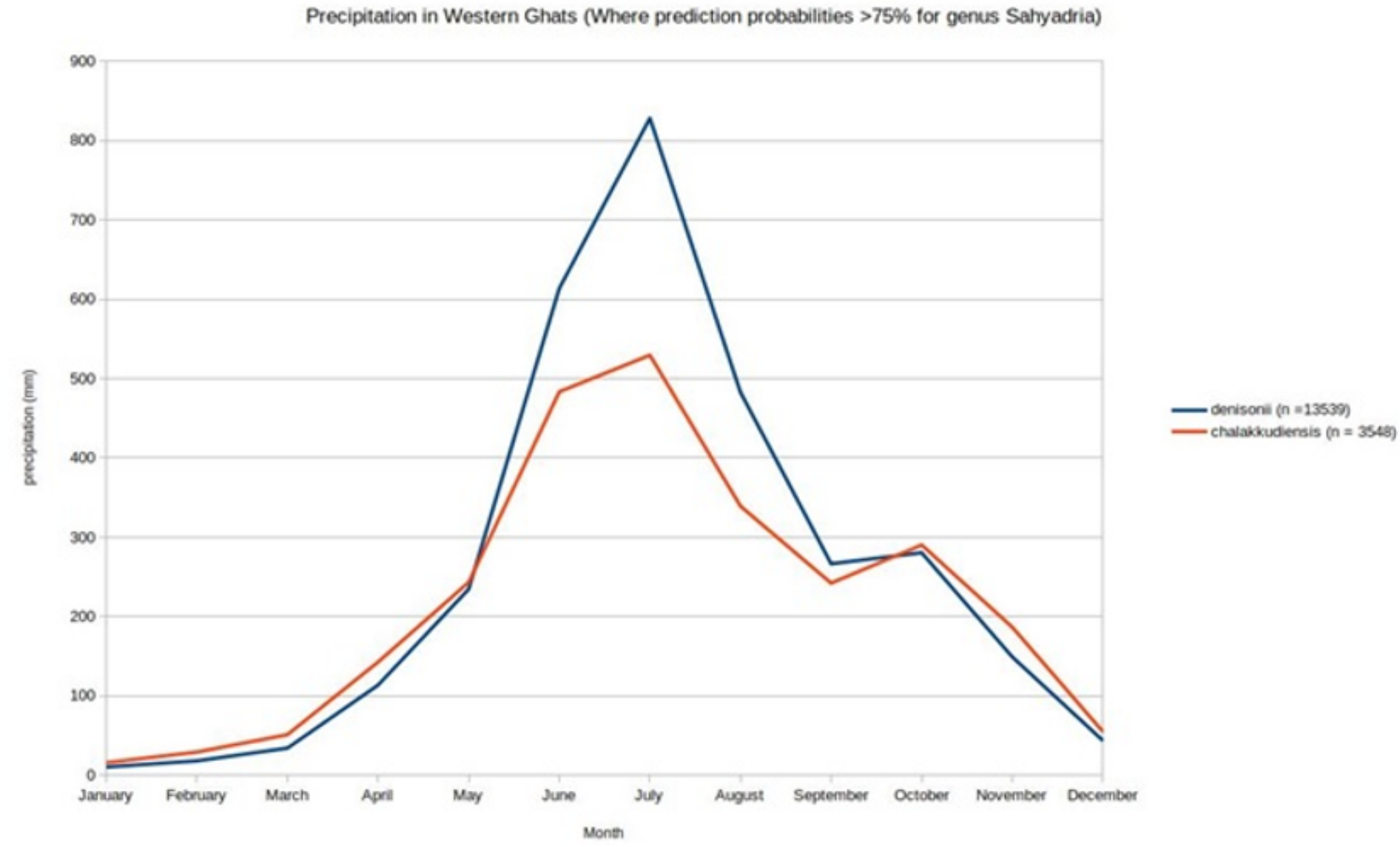

\section{Figure 5}

Annual Precipitation in the predicted habitat of Sahyadria denisonii and Sahyadria chalakkudiensis (with prediction probability $>75 \%$ ) 